\title{
Protein hyperproduction in fungi by design
}

\author{
Scott E. Baker ${ }^{1,2}$ (D) \\ Received: 1 June 2018 / Revised: 17 July 2018 / Accepted: 19 July 2018 / Published online: 4 August 2018 \\ (C) The Author(s) 2018
}

\begin{abstract}
The secretion of enzymes used by fungi to digest their environment has been exploited by humans for centuries for food and beverage production. More than a century after the first biotechnology patent, we know that the enzyme cocktails secreted by these amazing organisms have tremendous use across a number of industrial processes. Secreting the maximum titer of enzymes is critical to the economic feasibility of these processes. Traditional mutagenesis and screening approaches have generated the vast majority of strains used by industry for the production of enzymes. Until the emergence of economical next generation DNA sequencing platforms, the majority of the genes mutated in these screens remained uncharacterized at the sequence level. In addition, mutagenesis comes with a cost to an organism's fitness, making tractable rational strain design approaches an attractive alternative. As an alternative to traditional mutagenesis and screening, controlled manipulation of multiple genes involved in processes that impact the ability of a fungus to sense its environment, regulate transcription of enzyme-encoding genes, and efficiently secrete these proteins will allow for rational design of improved fungal protein production strains.
\end{abstract}

Keywords Enzyme $\cdot$ Protein · Hyperproduction · Secretion · Biodesign · Fungi · Biotechnology

\section{Introduction}

Fungi are constantly digesting their environment, secreting degradative enzymes, and absorbing the building block nutrients that are released. For centuries, humans have endeavored to harness the secreted enzyme activity, largely for production of food and beverage products such as soy sauce or sake (Abe and Gomi 2008; Baker and Bennett 2007; Machida et al. 2008). However, as the diversity of characterized enzymatic activities grows, so too do the potential uses (reviewed in Østergaard and Olsen 2011). Since the issuance of the first biotechnology patent in 1894 focused on production of starch saccharification enzymes from Aspergillus oryzae (Takamine 1894), fungi have been used to understand the basic biology of enzymes and to develop systems for their industrial production for use in a variety of applications. For example, since World War II, pioneering research and development have been

Scott E. Baker

scott.baker@pnnl.gov

1 Department of Energy Joint BioEnergy Institute, Emeryville, CA 94608, USA

2 Biosystems Design and Simulation Group, Environmental Molecular Sciences Division, Earth and Biological Sciences Directorate, Pacific Northwest National Laboratory, Richland, WA 99352, USA performed in Trichoderma reesei, from basic research that includes the elucidation of the components for the cellulose degradation enzyme system (Reese 1976) to applied research that includes the development of strains such as T. reesei RUTC30 that are the parents of strains used by the industry to produce enzyme cocktails for lignocellulosic biofuel production (Peterson and Nevalainen 2012). In the case of lignocellulosic biofuel and bioproduct production, where an enzyme or enzyme cocktail rather than the enzymatic process is being sold, a key factor for economic viability of enzyme sales is the cost and efficiency of enzyme production (KleinMarcuschamer et al. 2012).

Over the last century, traditional forward genetic mutagenesis and screening methods have been utilized to generate strains with increased titer, rates, and yields of desired secreted enzymes. For example, Aspergillus niger strains with improved production of multiple types of enzymes, including glucoamylase (Armbruster 1961; Hu et al. 2017; Nevalainen 1981; Tahoun 1993) and T. reesei strains that produce high titers of cellulase (Mandels et al. 1971; Montenecourt and Eveleigh 1977; Peterson and Nevalainen 2012), have been generated by a variety of mutagenesis and screening regimes. With the continued industrialization and decreasing cost of DNA sequencing, it is now possible to "resequence" these mutant strains, identify mutations of interest, and assess mutations in a "clean" genetic background for their effect on 
enzyme secretion using reverse genetic methods (Baker 2009; Baker and Bredeweg 2016; Ivanova et al. 2017; Koike et al. 2013; Le Crom et al. 2009; Lichius et al. 2015; Nitta et al. 2012; Vitikainen et al. 2010). In this way, a number of mutations have been characterized that have led to increased enzyme secretion (Nitta et al. 2012; Pei et al. 2015). Derivatives of mutagenized strains continue to be developed and used by the industry for production of enzymes (Schuster et al. 2002; van Dijck et al. 2003). Although mutagenesis is effective at generating strains that secrete significant titers of enzymes, strain improvement often comes with collateral genome damage. For example, in the case of T. reesei, the quest for strains hyperproducing cellulases also led to cellulose-negative strains (Druzhinina et al. 2006; Ivanova et al. 2017; Lichius et al. 2015; Torigoi et al. 1996). Moreover, it is only within the last decade that the sexual cycle of $T$. reesei was described and the possibility of classical genetic strategies for understanding and improving protein hyper-production explored (Jourdier et al. 2017; Kuck and Bohm 2013; Li et al. 2016; Linke et al. 2015; Seidl and Seiboth 2010; Tisch et al. 2017).

Beyond industrial biotechnology enzyme and small molecule production hosts, yeast and filamentous fungi are well studied as model systems for a number of biological processes that include, but are not limited to, protein secretion, cell signaling, cell morphology, and small molecule transport. Approaches from a breadth of biological disciplines, such as genetics, genomics, cell biology, physiology, molecular biology, and biochemistry have been used to understand the biological processes that underlie the fungal lifestyle. Decades of basic and applied fungal research spanning a breadth of methods has generated a knowledgebase that makes it possible to rationally design hypersecreting fungal enzyme production hosts.

This mini review focuses on a subset of biological processes involved in ascomycete production of carbohydrate-active enzymes (CAZymes). Enzymatic deconstruction of various plant biomass components is considered a critical step in the production of lignocellulosic biofuels, and there is a vast literature on the genetics, biochemistry, cell biology, and regulation of CAZyme secretion from ascomycetes. In the following sections, I describe three different biological processes that contribute to filamentous fungal enzyme secretion: (1) nutrient sensing; (2) transcriptional regulation, and (3) translation and secretion (Fig. 1). I also overview recent research that uses a rational design strategy for a filamentous fungal hypersecreting enzyme production host that incorporates manipulating genes whose products are involved in these biological processes.

\section{Nutrient sensing}

Fungi must balance the need to produce enzymes to digest complex substrates and provide building block nutrients with the level of available building block nutrients for absorption; the expense of secreting an enzyme must be balanced with nutritional return on the biosynthetic investment and growth rate. The first step in managing these trade-offs is to be able to sense the concentration of nutrients available for absorption. To accomplish this, fungi exploit a breadth of sensors that are the first step in "seeing" environmental conditions. Blinding the fungus to its nutritional landscape is one way to induce high expression of digestive enzymes relevant to industrial applications. In order to "blind" a fungus, deletion of the appropriate sensing proteins is critical. Over the last several decades, researchers have done much to increase this knowledge.

Early hints at the exquisite control exerted by filamentous fungi on absorption of sugars came from a study of a pyruvate carboxylase mutant of Aspergillus nidulans. In this mutant strain, growth on glucose resulted in secretion of pyruvate while growth on glucose in the presence of acetate resulted in pyruvate not being secreted, indicating that glucose was not being utilized by the organism (Romano and Kornberg 1969). This regulation of glucose uptake illustrated feedback from central metabolism to regulate sugar uptake and launched subsequent studies into sugar transport systems. A major early finding indicated distinct systems for uptake of specific sugars in A. nidulans and Neurospora crassa (Mark and Romano 1971; Scarborough 1970). Moreover, it was shown that both high- and low-affinity uptake systems exist for glucose and other sugars in these and other fungi (MacCabe et al. 2003; Schneider and Wiley 1971; Torres et al. 1996; Wang et al. 2017). Thus, it is apparent that fungi "see" the nutrient environment around them and are able to respond with appropriate enzymes and transporters needed for generation, uptake, and metabolism of these building blocks.

In $N$. crassa, a gene originally identified for its role in conidiation, $r \mathrm{ro}-3$, was cloned and sequenced and found to encode a protein with significant homology to known glucose transporters (Madi et al. 1997). Experimental results indicated that its function may be more complex than simply glucose transport. In experiments with 2-deoxy-D-glucose (2DG), a glucose analog that inhibits glycolosis and is used in studies of carbon catabolite repression, mutant $r c o-3$ strains exhibited glucose transport properties consistent with defects in the glucose repression system rather than a defect in a single glucose transporter (Ebbole 1998; Madi et al. 1997). Recently, other putative sugar transporters tied to carbon catabolite repression have been identified in $N$. crassa, A. nidulans and A. niger (Dos Reis et al. 2017; Reilly et al. 2018; Wang et al. 2017). In some instances, predicted transporters connected with activation of signaling networks have been called "transceptors" because they embody structure and/or behavior associated with transporters and receptors (Van Dijck et al. 2017).

G-protein-coupled receptors (GPCRs) are located at the plasma membrane, have seven transmembrane domains, and are centrally involved in environmental sensing and signaling. 
Fig. 1 Manipulation of genes that encode proteins involved in regulating nutrient sensing, transcription, translation, and secretion is key for rational design of fungal lignocellulosic deconstruction enzyme hypersecretors

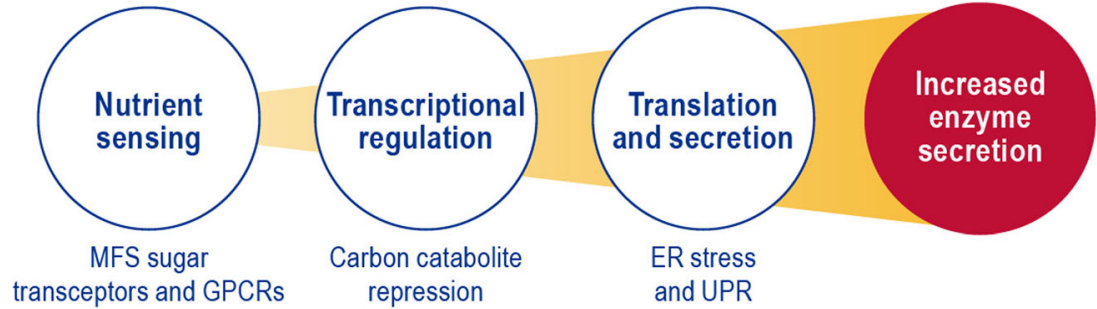

Several fungal GPCRs have been characterized, a subset of which are involved in sugar sensing (Xue et al. 2008). Both $N$. crassa and A. nidulans have GPCRs that have been identified and characterized as being involved in carbon source sensing (Brown et al. 2015; Li and Borkovich 2006). When GPCRs are activated, adenylate cyclase increases levels of cyclic AMP, which in turn activates protein kinase A (PKA) downstream signaling cascades. One target of this activity is carbon catabolite repression; molecular genetic studies in A. nidulans and $T$. reesei indicate that PKA influences expression of hydrolases (de Assis et al. 2015; Schuster et al. 2012).

\section{Transcriptional regulation}

GPCRs and sugar transporters/transceptors are the first line of environmental sensing feeding into the signaling networks that regulate gene expression and protein secretion. While the mechanisms that exquisitely regulate the carbon catabolite repression system and secretion of lignocellulosic deconstruction enzymes of fungi can differ, some elements of the core control system players are conserved (Benocci et al. 2017; Klaubauf et al. 2014). The gene encoding the master controller for carbon catabolite repression was initially discovered in Saccharomyces cerevisiae and named migl (multicopy inhibitor of galactose promoter) (Mercado et al. 1991; Nehlin et al. 1991; Nehlin and Ronne 1990). Overexpression of migl represses carbon catabolism, while deletion of migl predictably affects glucose repression (Nehlin and Ronne 1990). Additional work in $S$. cerevisiae and other yeasts of the Saccharomycotina has shown that the kinase Snflp plays an important role in Miglp activity via phosphorylation (Matsuzawa et al. 2012; Rippert et al. 2017; Treitel et al. 1998).

In filamentous ascomycetes, the ortholog of mig 1 is named creA (Aspergillus) or crel (Trichoderma and Neurospora). Aspergillus nidulans creA was originally identified by suppressor screens in a nitrogen metabolite repression mutant background ( $a r e A^{-}$) (Arst and Cove 1973). creA was later cloned, and orthologues to $c r e A$ have been identified in several other fungi (Cepeda-García et al. 2014; de la Serna et al. 1999; Dowzer and Kelly 1989; Drysdale et al. 1993; Ilmen et al. 1996; Jekosch and Kück 2000; Liu et al. 2013; Tudzynski et al. 2000; Vautard et al. 1999; Wang et al. 2015). Recent research on $A$. niger indicates that sequential uptake of different sugar monomers into the cell is regulated separately from metabolism and not by creA (Mäkelä et al. 2018).

In the RUT-C30 lineage of T. reesei, crel is truncated with the mutation occurring in the last stage of mutagenesis on 2DG, highlighting the central role of CRE1 in carbon catabolite repression (Ilmen et al. 1996; Le Crom et al. 2009; Montenecourt and Eveleigh 1977). Subsequent studies indicated that the CRE1 truncation in RUT-C30 (cre1-1) and a complete deletion of crel had identical phenotypes, carbon catabolite derepression, and increased hydrolysis enzyme secretion (Nakari-Setala et al. 2009). Post-translational modifications are known to play an important role in crel function; phosphorylation impacts DNA binding in multiple ways depending on the organism (Cziferszky et al. 2002; VautardMey and Fevre 2000). The isolation of $c r e B$, a predicted deubiquitination enzyme as a suppressor of $c r e A$, points toward a role of ubiquitination in regulation of CREA/1 function although a detailed mechanism remains unknown. Furthermore, F-box proteins that are part of the complex that comprise the SCF family of E3 ubiquitin ligases (Skowyra et al. 1997) interact genetically with $\mathrm{creA} / 1$ (Colabardini et al. 2012; Jonkers and Rep 2009).

\section{Translation and secretion}

The protein secretion pathway of yeast and filamentous fungi is of high interest as a target for modification in order to increase secretion of proteins. Fungal protein secretion has been explored at all stages, from protein targeting to ER to secretion and subsequent degradation by proteases with the goal of improving titer, rate, and yield of target proteins. The cellular response to ER stress, often referred to as the unfolded protein response or UPR, plays an important role in protein secretion inducing the expression of chaperones and other proteins that aid in folding and protein trafficking efficiency (Malavazi et al. 2014; Mori 2015; Nawkar et al. 2018; Smith and Wilkinson 2017). Activation of the unfolded protein response or UPR pathway is highly conserved and has been well described in a number of eukaryotic systems (Malavazi et al. 2014; Mori 2015; Nawkar et al. 2018; Smith and Wilkinson 2017). 
The UPR has been extensively studied in S. cerevisiae, where various screens identified UPR genes (Mori 2015; Mori et al. 1996). A transcription factor, Haclp, was shown to be spliced by an unconventional mechanism involving Ire1p (Cox and Walter 1996; Kawahara et al. 1997). This mechanism is conserved in other yeast, filamentous fungi, and other eukaryotes (Guerfal et al. 2010; Hooks and Griffiths-Jones 2011; Mulder et al. 2004; Saloheimo et al. 2003; Whyteside et al. 2011). Once activated, the UPR leads to increased expression of proteins involved in protein folding. In addition, the UPR is known to be involved in ER-associated degradation (ERAD) (Travers et al. 2000) and repression under secretion stress (RESS), which balance ER stress by degrading unfolded proteins and repressing expression of secreted proteins respectively (Pakula et al. 2003). It stands to reason that overexpression of an activated HAC1/A would have a positive impact on protein secretion, producing properly folded proteins while decreasing stress on the ER. This has been demonstrated in a variety of systems, often for heterologous protein production with inducible expression of activated HAC1/A being more effective than constitutive expression (Carvalho et al. 2012; Guerfal et al. 2010; Valkonen et al. 2003a; Valkonen et al. 2003b; Wu et al. 2017). While induction of cellulase gene transcription is not HAC1 or IRE1 dependent, deletion of hac-1 from $N$. crassa results in significantly reduced growth when cellulose is the carbon source (Fan et al. 2015; MontenegroMontero et al. 2015). Furthermore, a number transcription factors downstream of $\mathrm{HAC} 1$ are involved in regulating lignocellulosic deconstruction enzyme-encoding genes, indicating a complex regulatory network influenced by ER stress and the UPR (Fan et al. 2015). Interestingly, the low cellulase production in hac-1 mutants is suppressed by mutations in sterol regulatory element-binding proteins (SREBPs) demonstrating a connection between the UPR and sterol and lipid metabolism (Qin et al. 2017; Reilly et al. 2015; Volmer and Ron 2015).

\section{Rational design}

Rational design of fungal lignocellulosic deconstruction enzyme hypersecretors should consider nutrient sensing, transcription, translation, and secretion. The availability of tools for genetic manipulation is critical to the rational design of fungal production strains. Approaches for developing transformation systems in filamentous fungi are well established (reviewed in Li et al. 2017a). Both gene deletion and overexpression are critical elements of strain design. In the case of gene overexpression, control of transcription is critical, and development of finely tuned regulatory systems has, for example, been demonstrated for cellulase expression in $N$. crassa (Matsu-Ura et al. 2018).

Penicillium oxalicum has been a target organism for rational design of lignocellulosic biomass deconstruction enzyme production ( $\mathrm{Li}$ et al. 2017b). Initially, traditional mutagenesis and screening methods were used to developed high-protein production strains. Initial strains developed have largely manipulated transcriptional regulators, including $c r e A$, and in subsequent work have generated an activated Xylanase regulator 1 (called $x \ln R(\mathrm{~A} 871 \mathrm{~V})$ as well as a chimeric $\operatorname{clr} B-x \ln R$ (A871B) (Derntl et al. 2013; Gao et al. 2017a; Gao et al. 2017b; Li et al. 2015; Yao et al. 2015). Similar combinatorial genetics have been developed in Myceliophthora thermophile, a thermophilic ascomycete. In this case, a CRISPR/Cas9 genome editing approach was utilized to combine mutations in genes whose products are involved in carbon catabolite repression, ER stress, and proteolysis (Liu et al. 2017). Future rational design of protein hyperproduction strains should combine nutrient sensing, transcriptional regulation, translation, and secretion (Fig. 1). Genetic manipulation of these processes has been shown to increase protein production. High-level transcriptional regulators (such as CREA/ 1 and HAC1/A) sugar transceptors and GPCRs as well as their downstream regulatory and signaling cascade proteins are potential targets for genetic manipulation for rational design of protein hyperproducers. A combinatorial approach to identifying synergistic interactions between deletion and controlled overexpression of these genes has the potential to yield highly productive strains with a minimum of non-productive phenotypes.

\section{Conclusions}

Fungi are amazing producers and secretors of enzymes: it is what they do to grow. These digestive enzymes cover a breadth of potential substrates: plant biomass, fungal biomass, proteinaceous substrates, and many others. The enzymes secreted to digest these materials have a huge range of applications for a variety of industries (Østergaard and Olsen 2011). Thus, the repertoire of digestive enzyme activities in combination with an ability to secrete a high titer of protein, make these organisms industrially intriguing. With our current knowledge of how fungi sense and respond to their nutritional environment, we can develop rational design strategies for protein hypersecretion. While I have elaborated on secretion of biomass degrading enzymes, the concept of (1) blinding the fungus to nutritional repression cues, (2) eliminating transcriptional repression, and (3) increasing protein translation and secretion efficiency can be applied to production of any class of enzyme involved in fungal digestive processes. 
Acknowledgements I thank Nathan Johnson for graphics support and Jeffrey Holmes for technical editing.

Funding information This work was generated with support from both the DOE Joint BioEnergy Institute (http://www.jbei.org), sponsored by the DOE's Office of Biological and Environmental Research, under Contract No. DE-AC02-05CH11231 with Lawrence Berkeley National Laboratory and the Environmental Molecular Sciences Laboratory (www.emsl.pnnl.gov), a national scientific user facility also sponsored by DOE's Office of Biological and Environmental Research located at Pacific Northwest National Laboratory. PNNL is operated by Battelle for the DOE under Contract DE-AC05-76RL01830.

\section{Compliance with ethical standards}

Ethical statement The author declares that he has no conflict of interest. This article does not contain any studies with human participants performed by the author.

Open Access This article is distributed under the terms of the Creative Commons Attribution 4.0 International License (http:// creativecommons.org/licenses/by/4.0/), which permits unrestricted use, distribution, and reproduction in any medium, provided you give appropriate credit to the original author(s) and the source, provide a link to the Creative Commons license, and indicate if changes were made.

\section{References}

Abe K, Gomi K (2008) Food products fermented by Aspergillus oryzae. The Aspergilli: Genomics, Medical Aspects, Biotechnology, and Research Methods 429-439

Armbruster FC (1961) Enzyme preparation United States patent 3012944,

Arst HN, Cove DJ (1973) Nitrogen metabolite repression in Aspergillus nidulans. Mol Gen Genomics 126(2):111-141

Baker SE (2009) Selection to sequence: opportunities in fungal genomics. Environ Microbiol 11(12):2955-2958. https://doi.org/10.1111/j. 1462-2920.2009.02112.x

Baker SE, Bennett JW (2007) An overview of the genus Aspergillus. The Aspergilli: Genomics, medical aspects, biotechnology, and research methods 3-13

Baker SE, Bredeweg EL (2016) Comparative genomics, resequencing and fast forward genetics in Aspergillus and Penicillium. Aspergillus and Penicillium in the post-genomic era 17-26 https:// doi.org/10.21775/9781910190395.02

Benocci T, Aguilar-Pontes MV, Zhou M, Seiboth B, de Vries RP (2017) Regulators of plant biomass degradation in ascomycetous fungi. Biotechnol Biofuels 10:152. https://doi.org/10.1186/s13068-0170841-x

Brown NA, Dos Reis TF, Ries LN, Caldana C, Mah JH, Yu JH, Macdonald JM, Goldman GH (2015) G-protein coupled receptormediated nutrient sensing and developmental control in Aspergillus nidulans. Mol Microbiol 98(3):420-439. https://doi.org/10.1111/ mmi. 13135

Carvalho ND, Jorgensen TR, Arentshorst M, Nitsche BM, van den Hondel CA, Archer DB, Ram AF (2012) Genome-wide expression analysis upon constitutive activation of the HacA bZIP transcription factor in Aspergillus niger reveals a coordinated cellular response to counteract ER stress. BMC Genomics 13:350. https://doi.org/10. 1186/1471-2164-13-350
Cepeda-García C, Domínguez-Santos R, García-Rico RO, GarcíaEstrada C, Cajiao A, Fierro F, Martín JF (2014) Direct involvement of the CreA transcription factor in penicillin biosynthesis and expression of the pcbAB gene in Penicillium chrysogenum. Appl Microbiol Biotechnol 98(16):7113-7124. https://doi.org/10.1007/ s00253-014-5760-1

Colabardini AC, Humanes AC, Gouvea PF, Savoldi M, Goldman MH, Kress MR, Bayram O, Oliveira JV, Gomes MD, Braus GH, Goldman GH (2012) Molecular characterization of the Aspergillus nidulans fbxA encoding an F-box protein involved in xylanase induction. Fungal Genet Biol 49(2):130-140. https://doi.org/10.1016/ j.fgb.2011.11.004

Cox JS, Walter P (1996) A novel mechanism for regulating activity of a transcription factor that controls the unfolded protein response. Cell 87(3):391-404

Cziferszky A, Mach RL, Kubicek CP (2002) Phosphorylation positively regulates DNA binding of the carbon catabolite repressor Cre1 of Hypocrea jecorina (Trichoderma reesei). J Biol Chem 277(17): 14688-14694. https://doi.org/10.1074/jbc.M200744200

de Assis LJ, Ries LN, Savoldi M, Dos Reis TF, Brown NA, Goldman GH (2015) Aspergillus nidulans protein kinase A plays an important role in cellulase production. Biotechnol Biofuels 8:213. https://doi.org/ 10.1186/s13068-015-0401-1

de la Serna I, Ng D, Tyler BM (1999) Carbon regulation of ribosomal genes in Neurospora crassa occurs by a mechanism which does not require Cre-1, the homologue of the Aspergillus carbon catabolite repressor, CreA. Fungal Genet Biol 26(3):253-269

Derntl C, Gudynaite-Savitch L, Calixte S, White T, Mach RL, MachAigner AR (2013) Mutation of the xylanase regulator 1 causes a glucose blind hydrolase expressing phenotype in industrially used Trichoderma strains. Biotechnol Biofuels 6(1):62. https://doi.org/ 10.1186/1754-6834-6-62

Dos Reis TF, Nitsche BM, de Lima PB, de Assis LJ, Mellado L, Harris SD, Meyer V, Dos Santos RA, Riano-Pachon DM, Ries LN, Goldman GH (2017) The low affinity glucose transporter HxtB is also involved in glucose signalling and metabolism in Aspergillus nidulans. Sci Rep 7:45073. https://doi.org/10.1038/srep45073

Dowzer CE, Kelly JM (1989) Cloning of the creA gene from Aspergillus nidulans: a gene involved in carbon catabolite repression. Curr Genet 15(6):457-459

Druzhinina IS, Schmoll M, Seiboth B, Kubicek CP (2006) Global carbon utilization profiles of wild-type, mutant, and transformant strains of Hypocrea jecorina. Appl Environ Microbiol 72(3):2126-2133. https://doi.org/10.1128/AEM.72.3.2126-2133.2006

Drysdale MR, Kolze SE, Kelly JM (1993) The Aspergillus niger carbon catabolite repressor encoding gene, creA. Gene 130(2):241-245

Ebbole DJ (1998) Carbon catabolite repression of gene expression and conidiation in Neurospora crassa. Fungal Genet Biol 25(1):15-21. https://doi.org/10.1006/fgbi.1998.1088

Fan F, Ma G, Li J, Liu Q, Benz JP, Tian C, Ma Y (2015) Genome-wide analysis of the endoplasmic reticulum stress response during lignocellulase production in Neurospora crassa. Biotechnol Biofuels 8:66. https://doi.org/10.1186/s13068-015-0248-5

Gao L, Li Z, Xia C, Qu Y, Liu M, Yang P, Yu L, Song X (2017a) Combining manipulation of transcription factors and overexpression of the target genes to enhance lignocellulolytic enzyme production in Penicillium oxalicum. Biotechnol Biofuels 10:100. https://doi. org/10.1186/s13068-017-0783-3

Gao L, Xia C, Xu J, Li Z, Yu L, Liu G, Song X, Qu Y (2017b) Constitutive expression of chimeric transcription factors enables cellulase synthesis under non-inducing conditions in Penicillium oxalicum. Biotechnol J 12(11) https://doi.org/10.1002/biot. 201700119

Guerfal M, Ryckaert S, Jacobs PP, Ameloot P, Van Craenenbroeck K, Derycke R, Callewaert N (2010) The HAC1 gene from Pichia pastoris: characterization and effect of its overexpression on the 
production of secreted, surface displayed and membrane proteins. Microb Cell Factories 9:49. https://doi.org/10.1186/1475-2859-9-49

Hooks KB, Griffiths-Jones S (2011) Conserved RNA structures in the non-canonical Hac1/Xbp1 intron. RNA Biol 8(4):552-556. https:// doi.org/10.4161/rna.8.4.15396

Hu W, Li W, Chen H, Liu J, Wang S, Chen J (2017) Changes in transcript levels of starch hydrolysis genes and raising citric acid production via carbon ion irradiation mutagenesis of Aspergillus niger. PLoS One 12(6):e0180120. https://doi.org/10.1371/journal.pone.0180120

Ilmen M, Thrane C, Penttila M (1996) The glucose repressor gene cre1 of Trichoderma: isolation and expression of a full-length and a truncated mutant form. Mol Gen Genet 251(4):451-460

Ivanova C, Ramoni J, Aouam T, Frischmann A, Seiboth B, Baker SE, Le Crom S, Lemoine S, Margeot A, Bidard F (2017) Genome sequencing and transcriptome analysis of Trichoderma reesei QM9978 strain reveals a distal chromosome translocation to be responsible for loss of vib1 expression and loss of cellulase induction. Biotechnol Biofuels 10:209. https://doi.org/10.1186/s13068-0170897-7

Jekosch K, Kück U (2000) Loss of glucose repression in an Acremonium chrysogenum $\beta$-lactam producer strain and its restoration by multiple copies of the crel gene. Appl Microbiol Biotechnol 54(4):556563

Jonkers W, Rep M (2009) Mutation of CRE1 in Fusarium oxysporum reverts the pathogenicity defects of the FRP1 deletion mutant. Mol Microbiol 74(5):1100-1113. https://doi.org/10.1111/j.1365-2958. 2009.06922.x

Jourdier E, Baudry L, Poggi-Parodi D, Vicq Y, Koszul R, Margeot A, Marbouty M, Bidard F (2017) Proximity ligation scaffolding and comparison of two Trichoderma reesei strains genomes. Biotechnol Biofuels 10:151. https://doi.org/10.1186/s13068-017-0837-6

Kawahara T, Yanagi H, Yura T, Mori K (1997) Endoplasmic reticulum stress-induced mRNA splicing permits synthesis of transcription factor $\mathrm{Hac} 1 \mathrm{p} / \mathrm{Ern} 4 \mathrm{p}$ that activates the unfolded protein response. Mol Biol Cell 8(10):1845-1862

Klaubauf S, Narang HM, Post H, Zhou M, Brunner K, Mach-Aigner AR, Mach RL, Heck AJR, Altelaar AFM, de Vries RP (2014) Similar is not the same: differences in the function of the (hemi-) cellulolytic regulator XlnR (Xlr1/Xyr1) in filamentous fungi. Fungal Genet Biol 72:73-81. https://doi.org/10.1016/j.fgb.2014.07.007

Klein-Marcuschamer D, Oleskowicz-Popiel P, Simmons BA, Blanch HW (2012) The challenge of enzyme cost in the production of lignocellulosic biofuels. Biotechnol Bioeng 109(4):1083-1087. https://doi.org/10.1002/bit.24370

Koike H, Aerts A, LaButti K, Grigoriev IV, Baker SE (2013) Comparative genomics analysis of Trichoderma reesei strains. Indust Biotechnol 9(6):352-367. https://doi.org/10.1089/ind.2013. 0015

Kuck U, Bohm J (2013) Mating type genes and cryptic sexuality as tools for genetically manipulating industrial molds. Appl Microbiol Biotechnol 97(22):9609-9620. https://doi.org/10.1007/s00253013-5268-0

Le Crom S, Schackwitz W, Pennacchio L, Magnuson JK, Culley DE, Collett JR, Martin J, Druzhinina IS, Mathis H, Monot F, Seiboth B, Cherry B, Rey M, Berka R, Kubicek CP, Baker SE, Margeot A (2009) Tracking the roots of cellulase hyperproduction by the fungus Trichoderma reesei using massively parallel DNA sequencing. Proc Natl Acad Sci U S A 106(38):16151-16156. https://doi.org/10. 1073/pnas.0905848106

Li D, Tang Y, Lin J, Cai W (2017a) Methods for genetic transformation of filamentous fungi. Microb Cell Factories 16(1):168. https://doi.org/ 10.1186/s12934-017-0785-7

Li L, Borkovich KA (2006) GPR-4 is a predicted G-protein-coupled receptor required for carbon source-dependent asexual growth and development in Neurospora crassa. Eukaryot Cell 5(8):1287-1300. https://doi.org/10.1128/EC.00109-06
Li W-C, Chuang Y-C, Chen C-L, Wang T-F (2016) Hybrid infertility: the dilemma or opportunity of applying sexual development to improve Trichoderma reesei industrial strains. Gene expression systems in fungi: advancements and applications. Springer, pp 351-359

Li Z, Liu G, Qu Y (2017b) Improvement of cellulolytic enzyme production and performance by rational designing expression regulatory network and enzyme system composition. Bioresour Technol 245(Pt B):1718-1726

Li Z, Yao G, Wu R, Gao L, Kan Q, Liu M, Yang P, Liu G, Qin Y, Song X, Zhong Y, Fang X, Qu Y (2015) Synergistic and dose-controlled regulation of cellulase gene expression in Penicillium oxalicum. PLoS Genet 11(9):e1005509. https://doi.org/10.1371/journal.pgen. 1005509

Lichius A, Bidard F, Buchholz F, Le Crom S, Martin J, Schackwitz W, Austerlitz T, Grigoriev IV, Baker SE, Margeot A, Seiboth B, Kubicek CP (2015) Genome sequencing of the Trichoderma reesei QM9136 mutant identifies a truncation of the transcriptional regulator XYR1 as the cause for its cellulase-negative phenotype. BMC Genomics 16:326. https://doi.org/10.1186/s12864-015-1526-0

Linke R, Thallinger GG, Haarmann T, Eidner J, Schreiter M, Lorenz P, Seiboth B, Kubicek CP (2015) Restoration of female fertility in Trichoderma reesei QM6a provides the basis for inbreeding in this industrial cellulase producing fungus. Biotechnol Biofuels 8:155. https://doi.org/10.1186/s13068-015-0311-2

Liu G, Zhang L, Qin Y, Zou G, Li Z, Yan X, Wei X, Chen M, Chen L, Zheng K, Zhang J, Ma L, Li J, Liu R, Xu H, Bao X, Fang X, Wang L, Zhong Y, Liu W, Zheng H, Wang S, Wang C, Xun L, Zhao GP, Wang T, Zhou Z, Qu Y (2013) Long-term strain improvements accumulate mutations in regulatory elements responsible for hyper-production of cellulolytic enzymes. Sci Rep 3:1569. https:// doi.org/10.1038/srep01569

Liu Q, Gao R, Li J, Lin L, Zhao J, Sun W, Tian C (2017) Development of a genome-editing CRISPR/Cas9 system in thermophilic fungal Myceliophthora species and its application to hyper-cellulase production strain engineering. Biotechnol Biofuels 10:1. https://doi.org/ 10.1186/s13068-016-0693-9

MacCabe AP, Miró P, Ventura L, Ramon D (2003) Glucose uptake in germinating Aspergillus nidulans conidia: involvement of the creA and sorA genes. Microbiol 149(8):2129-2136

Machida M, Yamada O, Gomi K (2008) Genomics of Aspergillus oryzae: learning from the history of koji mold and exploration of its future. DNA Res 15(4):173-183. https://doi.org/10.1093/dnares/dsn020

Madi L, McBride SA, Bailey LA, Ebbole DJ (1997) Rco-3, a gene involved in glucose transport and conidiation in Neurospora crassa. Genetics 146(2):499-508

Mäkelä MR, Aguilar-Pontes MV, van Rossen-Uffink D, Peng M, de Vries RP (2018) The fungus Aspergillus niger consumes sugars in a sequential manner that is not mediated by the carbon catabolite repressor CreA. Sci Rep 8 https://doi.org/10.1038/s41598-018-25152-x

Malavazi I, Goldman GH, Brown NA (2014) The importance of connections between the cell wall integrity pathway and the unfolded protein response in filamentous fungi. Brief Funct Genomics 13(6): 456-470. https://doi.org/10.1093/bfgp/elu027

Mandels M, Weber J, Parizek R (1971) Enhanced cellulase production by a mutant of Trichoderma viride. Appl Microbiol 21(1):152-154

Mark CG, Romano AH (1971) Properties of the hexose transport systems of Aspergillus nidulans. Biochimica et Biophysica Acta (BBA)Biomembranes 249(1):216-226

Matsu-Ura T, Dovzhenok AA, Coradetti ST, Subramanian KR, Meyer DR, Kwon JJ, Kim C, Salomonis N, Glass NL, Lim S, Hong CI (2018) Synthetic gene network with positive feedback loop amplifies Cellulase gene expression in Neurospora crassa. ACS Synth Biol 7(5):1395-1405. https://doi.org/10.1021/acssynbio. 8 b00011

Matsuzawa T, Fujita Y, Tohda H, Takegawa K (2012) Snfl-like protein kinase Ssp2 regulates glucose derepression in Schizosaccharomyces 
pombe. Eukaryot Cell 11(2):159-167. https://doi.org/10.1128/EC. 05268-11

Mercado JJ, Vincent O, Gancedo JM (1991) Regions in the promoter of the yeast FBP1 gene implicated in catabolite repression may bind the product of the regulatory gene MIG1. FEBS Lett 291(1):97-100

Montenecourt BS, Eveleigh DE (1977) Preparation of mutants of Trichoderma reesei with enhanced cellulase production. Appl Environ Microbiol 34(6):777-782

Montenegro-Montero A, Goity A, Larrondo LF (2015) The bZIP transcription factor HAC-1 is involved in the unfolded protein response and is necessary for growth on cellulose in Neurospora crassa. PLoS One 10(7):e0131415. https://doi.org/10.1371/journal.pone. 0131415

Mori K (2015) The unfolded protein response: the dawn of a new field. Proc Jpn Acad Ser B Phys Biol Sci 91(9):469-480. https://doi.org/ 10.2183/pjab.91.469

Mori K, Kawahara T, Yoshida H, Yanagi H, Yura T (1996) Signalling from endoplasmic reticulum to nucleus: transcription factor with a basic-leucine zipper motif is required for the unfolded proteinresponse pathway. Genes Cells 1(9):803-817

Mulder HJ, Saloheimo M, Penttila M, Madrid SM (2004) The transcription factor HACA mediates the unfolded protein response in Aspergillus niger, and up-regulates its own transcription. Mol Gen Genomics 271(2):130-140. https://doi.org/10.1007/s00438-0030965-5

Nakari-Setala T, Paloheimo M, Kallio J, Vehmaanpera J, Penttila M, Saloheimo M (2009) Genetic modification of carbon catabolite repression in Trichoderma reesei for improved protein production. Appl Environ Microbiol 75(14):4853-4860. https://doi.org/10. 1128/AEM.00282-09

Nawkar GM, Lee ES, Shelake RM, Park JH, Ryu SW, Kang CH, Lee SY (2018) Activation of the transducers of unfolded protein response in plants. Front Plant Sci 9:214. https://doi.org/10.3389/fpls.2018. 00214

Nehlin JO, Carlberg M, Ronne H (1991) Control of yeast GAL genes by MIG1 repressor: a transcriptional cascade in the glucose response. EMBO J 10(11):3373-3377

Nehlin JO, Ronne H (1990) Yeast MIG1 repressor is related to the mammalian early growth response and Wilms' tumour finger proteins. EMBO J 9(9):2891-2898

Nevalainen KM (1981) Induction, isolation, and characterization of Aspergillus niger mutant strains producing elevated levels of betagalactosidase. Appl Environ Microbiol 41(3):593-596

Nitta M, Furukawa T, Shida Y, Mori K, Kuhara S, Morikawa Y, Ogasawara W (2012) A new Zn (II) (2) Cys (6)-type transcription factor BglR regulates beta-glucosidase expression in Trichoderma reesei. Fungal Genet Biol 49(5):388-397. https://doi.org/10.1016/j. fgb.2012.02.009

Østergaard LH, Olsen HS (2011) Industrial applications of fungal enzymes. Industrial applications. Springer, pp 269-290

Pakula TM, Laxell M, Huuskonen A, Uusitalo J, Saloheimo M, Penttila M (2003) The effects of drugs inhibiting protein secretion in the filamentous fungus Trichoderma reesei. Evidence for downregulation of genes that encode secreted proteins in the stressed cells. J Biol Chem 278(45):45011-45020. https://doi.org/10.1074/ jbc.M302372200

Pei X, Fan F, Lin L, Chen Y, Sun W, Zhang S, Tian C (2015) Involvement of the adaptor protein 3 complex in lignocellulase secretion in Neurospora crassa revealed by comparative genomic screening. Biotechnol Biofuels 8:124. https://doi.org/10.1186/s13068-0150302-3

Peterson R, Nevalainen H (2012) Trichoderma reesei RUT-C30-thirty years of strain improvement. Microbiol 158(Pt 1):58-68. https:// doi.org/10.1099/mic.0.054031-0
Qin L, Wu VW, Glass NL (2017) Deciphering the regulatory network between the SREBP pathway and protein secretion in Neurospora crassa. MBio 8(2). https://doi.org/10.1128/mBio.00233-17

Reese ET (1976) History of the cellulase program at the U.S. army Natick development center. Biotechnol Bioeng Symp (6):9-20

Reilly MC, Kim J, Lynn J, Simmons BA, Gladden JM, Magnuson JK, Baker SE (2018) Forward genetics screen coupled with wholegenome resequencing identifies novel gene targets for improving heterologous enzyme production in Aspergillus niger. Appl Microbiol Biotechnol 102(4):1797-1807. https://doi.org/10.1007/ s00253-017-8717-3

Reilly MC, Qin L, Craig JP, Starr TL, Glass NL (2015) Deletion of homologs of the SREBP pathway results in hyper-production of cellulases in Neurospora crassa and Trichoderma reesei. Biotechnol Biofuels 8:121. https://doi.org/10.1186/s13068-0150297-9

Rippert D, Backhaus K, Rodicio R, Heinisch JJ (2017) Cell wall synthesis and central carbohydrate metabolism are interconnected by the SNF1/Mig1 pathway in Kluyveromyces lactis. Eur J Cell Biol 96(1): 70-81. https://doi.org/10.1016/j.ejcb.2016.12.004

Romano AH, Kornberg HL (1969) Regulation of sugar uptake by Aspergillus nidulans. Proc R Soc Ser B-bio 173(1033):475-+. https://doi.org/10.1098/rspb.1969.0072

Saloheimo M, Valkonen M, Penttila M (2003) Activation mechanisms of the HAC1-mediated unfolded protein response in filamentous fungi. Mol Microbiol 47(4):1149-1161

Scarborough GA (1970) Sugar transport in Neurospora crassa. J Biol Chem 245(7):1694-1698

Schneider R, Wiley W (1971) Kinetic characteristics of the two glucose transport systems in Neurospora crassa. J Bact 106(2):479-486

Schuster A, Tisch D, Seidl-Seiboth V, Kubicek CP, Schmoll M (2012) Roles of protein kinase a and adenylate cyclase in light-modulated cellulase regulation in Trichoderma reesei. Appl Environ Microbiol 78(7):2168-2178. https://doi.org/10.1128/AEM.06959-11

Schuster E, Dunn-Coleman N, Frisvad JC, Van Dijck PW (2002) On the safety of Aspergillus niger-a review. Appl Microbiol Biotechnol 59(4-5):426-435. https://doi.org/10.1007/s00253-002-1032-6

Seidl V, Seiboth B (2010) Trichoderma reesei: genetic approaches to improving strain efficiency. Biofuels 1(2):343-354. https://doi.org/ $10.4155 / \mathrm{bfs} .10 .1$

Skowyra D, Craig KL, Tyers M, Elledge SJ, Harper JW (1997) F-box proteins are receptors that recruit phosphorylated substrates to the SCF ubiquitin-ligase complex. Cell 91(2):209-219

Smith M, Wilkinson S (2017) ER homeostasis and autophagy. Essays Biochem 61(6):625-635. https://doi.org/10.1042/EBC20170092

Tahoun MK (1993) Intensification of glucose oxidase synthesis by multistage mutagenesis of Aspergillus niger Scientific note. Appl Biochem Biotechnol 39-40:289-295

Takamine J (1894) Process of making diastatic enzyme. United States patent 525823, September 11, 1894

Tisch D, Pomraning KR, Collett JR, Freitag M, Baker SE, Chen CL, Hsu PW, Chuang YC, Schuster A, Dattenbock C, Stappler E, Sulyok M, Bohmdorfer S, Oberlerchner J, Wang TF, Schmoll M (2017) Omics analyses of Trichoderma reesei CBS999.97 and QM6a indicate the relevance of female fertility to carbohydrate-active enzyme and transporter levels. Appl Environ Microbiol 83(22) https://doi.org/ 10.1128/AEM.01578-17

Torigoi E, Henrique-Silva F, Escobar-Vera J, Carle-Urioste JC, Crivellaro O, El-Dorry H, El-Gogary S (1996) Mutants of Trichoderma reesei are defective in cellulose induction, but not basal expression of cellulase-encoding genes. Gene 173(2):199-203

Torres N, Riol-Cimas J, Wolschek M, Kubicek C (1996) Glucose transport by Aspergillus niger: the low-affinity carrier is only formed during growth on high glucose concentrations. Appl Microbiol Biotechnol 44(6):790-794 
Travers KJ, Patil CK, Wodicka L, Lockhart DJ, Weissman JS, Walter P (2000) Functional and genomic analyses reveal an essential coordination between the unfolded protein response and ER-associated degradation. Cell 101(3):249-258

Treitel MA, Kuchin S, Carlson M (1998) Snfl protein kinase regulates phosphorylation of the Mig1 repressor in Saccharomyces cerevisiae. Mol Cell Biol 18(11):6273-6280

Tudzynski B, Liu S, Kelly JM (2000) Carbon catabolite repression in plant pathogenic fungi: isolation and characterization of the Gibberella fujikuroi and Botrytis cinerea creA genes. FEMS Microbiol Lett 184(1):9-15

Valkonen M, Penttila M, Saloheimo M (2003a) Effects of inactivation and constitutive expression of the unfolded-protein response pathway on protein production in the yeast Saccharomyces cerevisiae. Appl Environ Microbiol 69(4):2065-2072

Valkonen M, Ward M, Wang H, Penttila M, Saloheimo M (2003b) Improvement of foreign-protein production in Aspergillus niger var. awamori by constitutive induction of the unfolded-protein response. Appl Environ Microbiol 69(12):6979-6986

van Dijck PW, Selten GC, Hempenius RA (2003) On the safety of a new generation of DSM Aspergillus niger enzyme production strains. Regul Toxicol Pharmacol 38(1):27-35

Van Dijck, P, Brown NA, Goldman GH, Rutherford J, Xue C, Van GZ (2017) Nutrient sensing at the plasma membrane of fungal cells. Microbiol Spec 5(2) https://doi.org/10.1128/microbiolspec.FUNK0031-2016

Vautard-Mey G, Fevre M (2000) Mutation of a putative AMPK phosphorylation site abolishes the repressor activity but not the nuclear targeting of the fungal glucose regulator CRE1. Curr Genet 37(5): 328-332

Vautard G, Cotton P, Fevre M (1999) The glucose repressor CRE1 from Sclerotinia sclerotiorum is functionally related to CREA from Aspergillus nidulans but not to the Mig proteins from Saccharomyces cerevisiae. FEBS Lett 453(1-2):54-58

Vitikainen M, Arvas M, Pakula T, Oja M, Penttila M, Saloheimo M (2010) Array comparative genomic hybridization analysis of
Trichoderma reesei strains with enhanced cellulase production properties. BMC Genomics 11:441. https://doi.org/10.1186/1471-2164$11-441$

Volmer R, Ron D (2015) Lipid-dependent regulation of the unfolded protein response. Curr Opin Cell Biol 33:67-73. https://doi.org/10. 1016/j.ceb.2014.12.002

Wang B, Li J, Gao J, Cai P, Han X, Tian C (2017) Identification and characterization of the glucose dual-affinity transport system in Neurospora crassa: pleiotropic roles in nutrient transport, signaling, and carbon catabolite repression. Biotechnol Biofuels 10:17. https:// doi.org/10.1186/s13068-017-0705-4

Wang Q, Lin H, Shen Q, Fan X, Bai N, Zhao Y (2015) Characterization of cellulase secretion and Cre1-mediated carbon source repression in the potential lignocellulose-degrading strain Trichoderma asperellum T-1. PLoS One 10(3):e0119237. https://doi.org/10. 1371/journal.pone.0119237

Whyteside G, Nor RM, Alcocer MJ, Archer DB (2011) Activation of the unfolded protein response in Pichia pastoris requires splicing of a HAC1 mRNA intron and retention of the C-terminal tail of Hac1p. FEBS Lett 585(7):1037-1041. https://doi.org/10.1016/j.febslet. 2011.02.036

Wu Y, Sun X, Xue X, Luo H, Yao B, Xie X, Su X (2017) Overexpressing key component genes of the secretion pathway for enhanced secretion of an Aspergillus niger glucose oxidase in Trichoderma reesei. Enzym Microb Technol 106:83-87. https://doi.org/10.1016/j. enzmictec.2017.07.007

Xue C, Hsueh YP, Heitman J (2008) Magnificent seven: roles of G protein-coupled receptors in extracellular sensing in fungi. FEMS Microbiol Rev 32(6):1010-1032. https://doi.org/10.1111/j.15746976.2008.00131.x

Yao G, Li Z, Gao L, Wu R, Kan Q, Liu G, Qu Y (2015) Redesigning the regulatory pathway to enhance cellulase production in Penicillium oxalicum. Biotechnol Biofuels 8:71. https://doi.org/10.1186/ s13068-015-0253-8 